\title{
Exploring the Effects of Solar Radiation Management on Water Cycling in a Coupled Land-Atmosphere Model*
}

\author{
KATHERINE DAGON AND DANIEL P. SCHRAG \\ Department of Earth and Planetary Sciences, Harvard University, Cambridge, Massachusetts
}

(Manuscript received 9 July 2015, in final form 27 January 2016)

\begin{abstract}
Solar radiation management (SRM) has been proposed as a form of geoengineering to reduce the climate effects of anthropogenic greenhouse gas emissions. Modeling studies have concluded that SRM, through a reduction in total solar irradiance by approximately $2 \%$, roughly compensates for global mean temperature changes from a doubling of carbon dioxide concentrations. This paper examines the impact of SRM on the terrestrial hydrologic cycle using the Community Land Model, version 4, coupled to the Community Atmosphere Model, version 4, with reductions in solar radiation relative to simulations with present-day and elevated $\mathrm{CO}_{2}$ concentrations. There are significant global and regional impacts due to vegetation-climate interactions that are not compensated when reductions in total solar irradiance of $1 \%, 2 \%$, and $3 \%$ are imposed on top of a doubling of present-day $\mathrm{CO}_{2}$ concentrations. Water cycling slows down under SRM, including decreases in global mean precipitation and evapotranspiration. Changes in runoff and soil moisture are spatially and temporally variable, with implications for local water availability. In the tropics, evapotranspiration decreases because of increases in vegetation water use efficiency. In northern midlatitudes, soil moisture increases when evapotranspiration decreases, with some exceptions during boreal summer. Changes in soil evaporation influence water cycling in the southern subtropics, rather than changes in transpiration. The hydrologic response to SRM is nonlinear, with global mean decreases greater than expected. These results imply that SRM may not compensate for higher greenhouse gas concentrations when one considers land-atmosphere interactions.
\end{abstract}

\section{Introduction}

Even if drastic cuts in carbon emissions started today, fossil fuel emissions will remain in the atmosphere for thousands of years (Archer and Brovkin 2008). In addition to mitigation and adaptation, other options for counteracting climate change have been proposed, such as intentional climate interventions in the form of geoengineering (Crutzen 2006; Wigley 2006; Rasch et al. 2008; MacCracken 2009; Shepherd and Rayner 2009; Keith and MacMartin 2015). This work studies the climate impacts of geoengineering by solar radiation management (SRM). By reducing the amount of total solar irradiance, we approximate the injection of sulfate

\footnotetext{
* Supplemental information related to this paper is available at the Journals Online website: http://dx.doi.org/10.1175/JCLI-D-150472.s1.

Corresponding author address: Katherine Dagon, Harvard University, 20 Oxford Street, Cambridge, MA 02138.

E-mail: kdagon@fas.harvard.edu
}

aerosols into the stratosphere to reflect incoming solar radiation, cooling the surface of Earth. While some studies find the climate response to SRM differs when using stratospheric aerosols in place of reduced solar radiation (Fyfe et al. 2013; Niemeier et al. 2013; Ferraro et al. 2014), one recent study finds little effect (Kalidindi et al. 2015).

There is natural evidence that sulfur works to cool the planet based on observations after volcanic eruptions. After the 1991 eruption of Mount Pinatubo, globally averaged surface temperature decreased by about $0.5^{\circ} \mathrm{C}$ (Self et al. 1996; Soden et al. 2002; Crutzen 2006). Recent studies have also observed a decrease in precipitation after large volcanic eruptions, largely due to aerosol surface cooling reducing the latent heat flux of water vapor from the surface to the atmosphere (Gillett et al. 2004; Trenberth and Dai 2007; Iles et al. 2013). Other studies have shown that changes in shortwave forcing, such as solar variability or volcanic eruptions, are more effective in driving precipitation changes than the equivalent $\mathrm{CO}_{2}$ forcing (Allen and Ingram 2002; O'Gorman et al. 2012). Because latent heat flux will 
respond more strongly to changes in shortwave radiation than changes in longwave radiation, evaporation is expected to decrease under SRM (Andrews et al. 2009; Bala et al. 2010; Cao et al. 2012; Kleidon and Renner 2013; Tilmes et al. 2013; Curry et al. 2014).

A major uncertainty in the climate response to anthropogenic emissions is $\mathrm{CO}_{2}$ fertilization, or changes in the interaction between plants and climate due to elevated $\mathrm{CO}_{2}$ altering stomatal conductance and photosynthesis (Bala et al. 2006; Betts et al. 2007; DoutriauxBoucher et al. 2009; Lammertsma et al. 2011). Studies separating the $\mathrm{CO}_{2}$ radiative effect from the physiological effect have shown that the latter strongly influences water cycling through decreasing transpiration (Sellers et al. 1996a; Boucher et al. 2009; Cao et al. 2009, 2010; Andrews et al. 2011). A decrease in transpiration can lead to an increase in plant water use efficiency, defined as the ratio of photosynthesis to evapotranspiration. The total climate response under increased $\mathrm{CO}_{2}$ will be strongly influenced by plant physiology because of the interaction of productivity and transpiration (Field et al. 1995; Robock and Li 2006; Lee et al. 2012; Franks et al. 2013; Peng et al. 2014). Water cycling in plants can induce feedbacks on the atmosphere directly or indirectly through water stored in the soil. Soil moisture changes have corresponding impacts on surface temperature variability (Lenderink et al. 2007; Seneviratne et al. 2010; Hirschi et al. 2011; Fischer et al. 2012). Moisture deficits in particular can lead to the occurrence of extreme events, such as heat waves and droughts (Fischer et al. 2007; Lorenz et al. 2010; Mueller and Seneviratne 2012; Teuling et al. 2013; Miralles et al. 2014).

Past modeling studies have examined the impacts of SRM on climate and shown that uniform reductions in the solar constant can roughly compensate for globally averaged surface warming from a doubling and quadrupling of $\mathrm{CO}_{2}$ concentrations (Govindasamy and Caldeira 2000; Govindasamy et al. 2003; Caldeira and Wood 2008; Kravitz et al. 2013a). Similar studies have also observed a decrease in the pole-to-equator temperature gradient and a slowdown of the hydrologic cycle, including a decrease in global mean, annual mean precipitation (Bala et al. 2008; Ammann et al. 2010; Ricke et al. 2010; McCusker et al. 2012; Schmidt et al. 2012; Kravitz et al. 2013b; Niemeier et al. 2013; Tilmes et al. 2013; Kalidindi et al. 2015). These studies have primarily focused on global mean, annual mean surface temperature and precipitation changes due to SRM and do not explore changes in land-atmosphere water cycling in detail. Some studies consider vegetation-climate feedbacks and plant physiology (Fyfe et al. 2013; Irvine et al. 2014; Glienke et al. 2015) but not soil moisture and runoff. Of particular importance are how those factors are parameterized, how well constrained are the parameterizations in terms of observations, and how variations within reasonable ranges of plausible parameterizations will affect the results.

In this paper, we explore water cycling under SRM in a coupled land-atmosphere climate model. We examine regional and seasonal responses in evapotranspiration, runoff, and soil moisture, highlighting changes in water cycling and land-atmosphere coupling under $\mathrm{SRM}$ and elevated $\mathrm{CO}_{2}$. We examine changes from SRM relative to a control with present-day $\mathrm{CO}_{2}$ levels, as well as a control with elevated $\mathrm{CO}_{2}$ levels. The former helps to show the linear part of the climate impacts of SRM, while the latter highlights the tradeoffs between geoengineering and a greenhouse world. Models can amplify the response of solar forcing when simulated in conjunction with greenhouse gas forcing, providing motivation for investigating the coupled response versus single-forcing simulations (Meehl et al. 2003; Schaller et al. 2014). By exploring land surface parameterizations, this study also highlights how model formulations strongly influence the resulting vegetation-climate responses and feedbacks.

\section{Methods}

This study uses the Community Land Model, version 4 (CLM4) (Oleson et al. 2010), a dynamic land surface model developed by the National Center for Atmospheric Research (NCAR). We couple the land model to an atmospheric general circulation model also developed by NCAR, the Community Atmosphere Model, version 4 (CAM4). CAM4 uses a finite-volume solution for the dynamical equations. We also couple the atmospheric model to a slab ocean model (SOM) with a thermodynamic sea ice model. The slab ocean model solves for mixed layer temperatures using prescribed mixed layer depths and surface heat fluxes. Vertical and horizontal heat fluxes in and out of the mixed layer are from a fully coupled simulation. We run the model with a horizontal resolution of $1.9^{\circ}$ in latitude and $2.5^{\circ}$ in longitude, with 26 vertical levels in the atmosphere.

CLM4 separates grid cells into land surface type and simulates vertical moisture transport in a multilayer soil column model (Oleson et al. 2010). Vegetated land units are further partitioned into 16 possible plant functional types (PFT), prescribed by satellite observations in the current modeling setup (Bonan et al. 2002). Leaf and steam area indices are also fixed and derived from monthly satellite data (Oleson et al. 2010). The model couples leaf stomatal conductance, needed for calculating transpiration, to leaf photosynthesis (Farquhar et al. 1980) and scales conductance with relative humidity and $\mathrm{CO}_{2}$ concentration at the leaf surface (Ball et al. 1987; Collatz et al. 1991; Sellers et al. 1996b, 1997). At each time step, the model 
TABLE 1. Details of model simulations, including $\mathrm{CO}_{2}$ levels in the land and atmosphere model components, changes in solar radiation, and changes in initial sea surface temperature (SST) conditions.

\begin{tabular}{|c|c|c|c|c|}
\hline Simulation name & Atmospheric $\mathrm{CO}_{2}(\mathrm{ppm})$ & Land surface $\mathrm{CO}_{2}(\mathrm{ppm})$ & Solar irradiance & Initial conditions \\
\hline $1 \mathrm{xCO}_{2}$ & 400 & 400 & - & - \\
\hline Radiative & 800 & 400 & - & $\mathrm{SST}+3^{\circ} \mathrm{C}$ \\
\hline Physiological & 400 & 800 & - & - \\
\hline $2 \mathrm{xCO}_{2}$ & 800 & 800 & - & $\mathrm{SST}+3^{\circ} \mathrm{C}$ \\
\hline $1 \%$ SRM & 800 & 800 & $1 \%$ reduction & $\mathrm{SST}+1^{\circ} \mathrm{C}$ \\
\hline $2 \% \mathrm{SRM}$ & 800 & 800 & $2 \%$ reduction & - \\
\hline $3 \% \mathrm{SRM}$ & 800 & 800 & $3 \%$ reduction & $\mathrm{SST}-1^{\circ} \mathrm{C}$ \\
\hline
\end{tabular}

solves the equations for surface energy balance, surface water balance, and land-atmosphere carbon exchange.

The model represents soil hydrology with a 50-m-depth ground column divided into 10 soil layers and 5 bedrock layers, the latter of which are hydrologically inactive (Lawrence et al. 2011). The default configuration has the soil layers spanning a depth of almost $3 \mathrm{~m}$, with layers of variable thickness that exponentially decrease with depth to obtain more soil layers near the surface where the soil gradient is strong (Oleson et al. 2010). CLM4 includes a modified hydrology setup to calculate vertical soil water movement and a revised parameterization of ground evaporation to account for litter resistance and canopy stability (Lawrence et al. 2011). Both of these lead to improvements in soil hydrology and surface evaporative fluxes over the previous version of the model. The inclusion of a soil-dependent empirical factor to represent diffusion from soil pore to surface improves the partitioning of evapotranspiration (Lee and Pielke 1992; Sakaguchi and Zeng 2009). Ground evaporation now accounts for surface litter and undercanopy air, which improves soil evaporation over vegetated areas containing very wet soils.

Soil moisture variability relative to observations is still weak in CLM4, despite improvements from older versions of the model, but the observations themselves are limited and do not act as a strong constraint (Lawrence et al. 2011). One recent study finds the model underestimates soil evaporation when the soil is dry and overestimates it when the atmospheric resistance is low (Tang and Riley 2013). The Clapp and Hornberger soil pore size factor is an empirically derived exponential scaling used for calculating hydraulic conductivity and soil matric potential in the model, and it increases with soil texture from coarseto fine-grained soils. However, the experiment from which this data was derived had no replications, so it is impossible to assess experimental errors, though they may be a significant factor in the large reported residuals (Clapp and Hornberger 1978).

We use this modeling framework to explore the sensitivity of vegetation and surface hydrology to radiative forcing, both by changing $\mathrm{CO}_{2}$ concentrations and incoming solar radiation to simulate SRM. Table 1 describes the simulations in detail. We simulate a primary control run with present-day $\mathrm{CO}_{2}$ concentrations of $400 \mathrm{ppm}$ (herein referred to as $1 \mathrm{xCO}_{2}$ ). We construct simulations to separate the $\mathrm{CO}_{2}$ radiative and physiological effects by allowing only the atmosphere to see elevated $\mathrm{CO}_{2}$ of $800 \mathrm{ppm}$ (Radiative), and allowing only the land surface and vegetation to see elevated $\mathrm{CO}_{2}$ of 800 ppm (Physiological). We also perform a total $\mathrm{CO}_{2}$ simulation, in which both the atmosphere and the land see elevated $\mathrm{CO}_{2}$ of $800 \mathrm{ppm}$, to examine the relative importance of the individual $\mathrm{CO}_{2}$ effects and to act as a secondary control run for SRM comparisons $\left(2 \mathrm{xCO}_{2}\right)$. We simulate SRM using three different uniform reductions in top of the atmosphere solar irradiance (1\% SRM, $2 \% \mathrm{SRM}$, and $3 \% \mathrm{SRM}$ ). A reduction in solar radiation by approximately $2.1 \%$ is sufficient to offset warming from a doubling of $\mathrm{CO}_{2}$ (Kravitz et al. 2015). All simulations consist of monthly mean output run for $50 \mathrm{yr}$, with the last $20 \mathrm{yr}$ averaged in the analysis to study climate changes.

We accelerate the model spinup time by uniformly increasing sea surface temperatures to roughly doubled $\mathrm{CO}_{2}$ equilibrated values, relative to a reference $\mathrm{CO}_{2}$ concentration of $400 \mathrm{ppm}$ to mimic present-day (Cess et al. 1990; Cao et al. 2010; Bitz et al. 2012; Gettelman et al. 2012; Meehl et al. 2013). The model simulations have all equilibrated after $30 \mathrm{yr}$, consistent with similar analyses (Bala et al. 2008; Danabasoglu and Gent 2009; Bala et al. 2010; Kalidindi et al. 2015). We base our analysis of equilibrium on the standard deviation of a running 1-yr mean of global mean temperature for the last $20 \mathrm{yr}$ and linear trend of this running mean for the last $20 \mathrm{yr}$ (Fig. S1, Table S1 in the supplementary material).

\section{Results}

\section{a. Global mean changes}

Global mean surface temperature changes averaged over the last $20 \mathrm{yr}$ of the $1 \mathrm{xCO}_{2}$ simulation subtracted from the $2 \mathrm{xCO}_{2}$ simulation are dominated by the radiative effect of $\mathrm{CO}_{2}$ (Table S2, Fig. S3 in the supplementary material). Temperature changes are smaller in 


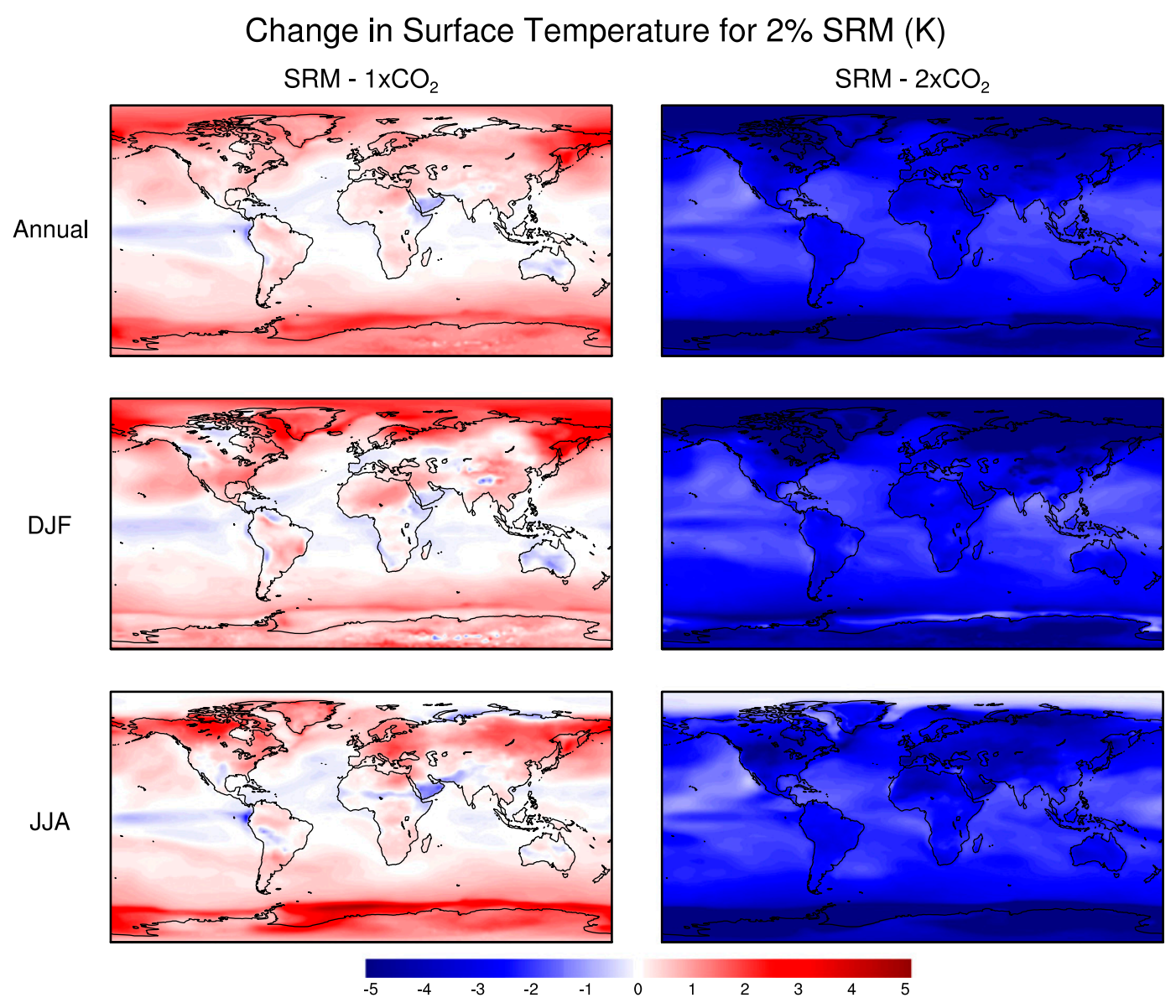

FIG. 1. Surface temperature changes (K) for the SRM simulation with a $2 \%$ reduction in solar constant, relative to (left) $1 \mathrm{xCO}_{2}$ and (right) $2 \mathrm{xCO}_{2}$. (top) Annual mean changes, (middle) DJF changes, and (bottom) JJA changes.

the $2 \mathrm{xCO}_{2}$ simulation than the sum of the Physiological and Radiative simulations. Elevated $\mathrm{CO}_{2}$ in the Physiological simulation drives a decrease in latent heat flux over land through stomatal closure. A warmer surface and atmosphere due to the Radiative simulation cause latent heat flux to increase, relative to $1 \mathrm{xCO}_{2}$. The $2 \mathrm{xCO}_{2}$ simulation results in a smaller increase in latent heat flux over land, as the decrease from the Physiological simulation moderates the increase from the Radiative simulation (Fig. S4 in the supplementary material). Global mean runoff (precipitation minus evapotranspiration over land) increases in both the Physiological (12.8\%) and Radiative $(16.7 \%)$ simulations, though the mechanisms differ. The Radiative simulation increases precipitation enough to overcome the increase in evapotranspiration (ET), and thus runoff increases. The Physiological simulation shows a small increase in precipitation over land, but the decrease in ET drives the runoff increase. Global mean runoff increases by $30.3 \%$ in the $2 \mathrm{xCO}_{2}$ simulation, greater than the sum of the individual simulations (Fig. S5 in the supplementary material). Global mean volumetric soil moisture of the top $10 \mathrm{~cm}$ increases for $2 \mathrm{xCO}_{2}$, though there is a lot of regional variability (Fig. S6 in the supplementary material). The Radiative simulation decreases global mean photosynthesis $(-3.5 \%)$ because of an increase in surface temperature. The Physiological and $2 \mathrm{xCO}_{2}$ simulations increase global mean photosynthesis by $34.4 \%$ and $31.0 \%$, respectively, because of $\mathrm{CO}_{2}$ fertilization exaggerated by the lack of nitrogen limitation in the current model setup.

Global mean surface temperature increases by $0.4 \mathrm{~K}$ in the $2 \%$ SRM simulation, relative to $1 \mathrm{xCO}_{2}$ (Fig. 1 and Table S3 in the supplementary material). Global mean latent heat flux over land decreases by $4.6 \%$ (Fig. 2). Transpiration changes are the largest contributor to total ET changes (Fig. 3). Transpiration decreases under SRM, while ground and canopy evaporation increase. Global mean precipitation decreases (Fig. 4), while runoff increases by $11.6 \%$ (Fig. 5) because of the decrease in ET. Annual mean volumetric soil moisture of the top $10 \mathrm{~cm}$ increases (Fig. 6). While there is considerable spatial variability, soil moisture generally decreases in boreal winter 

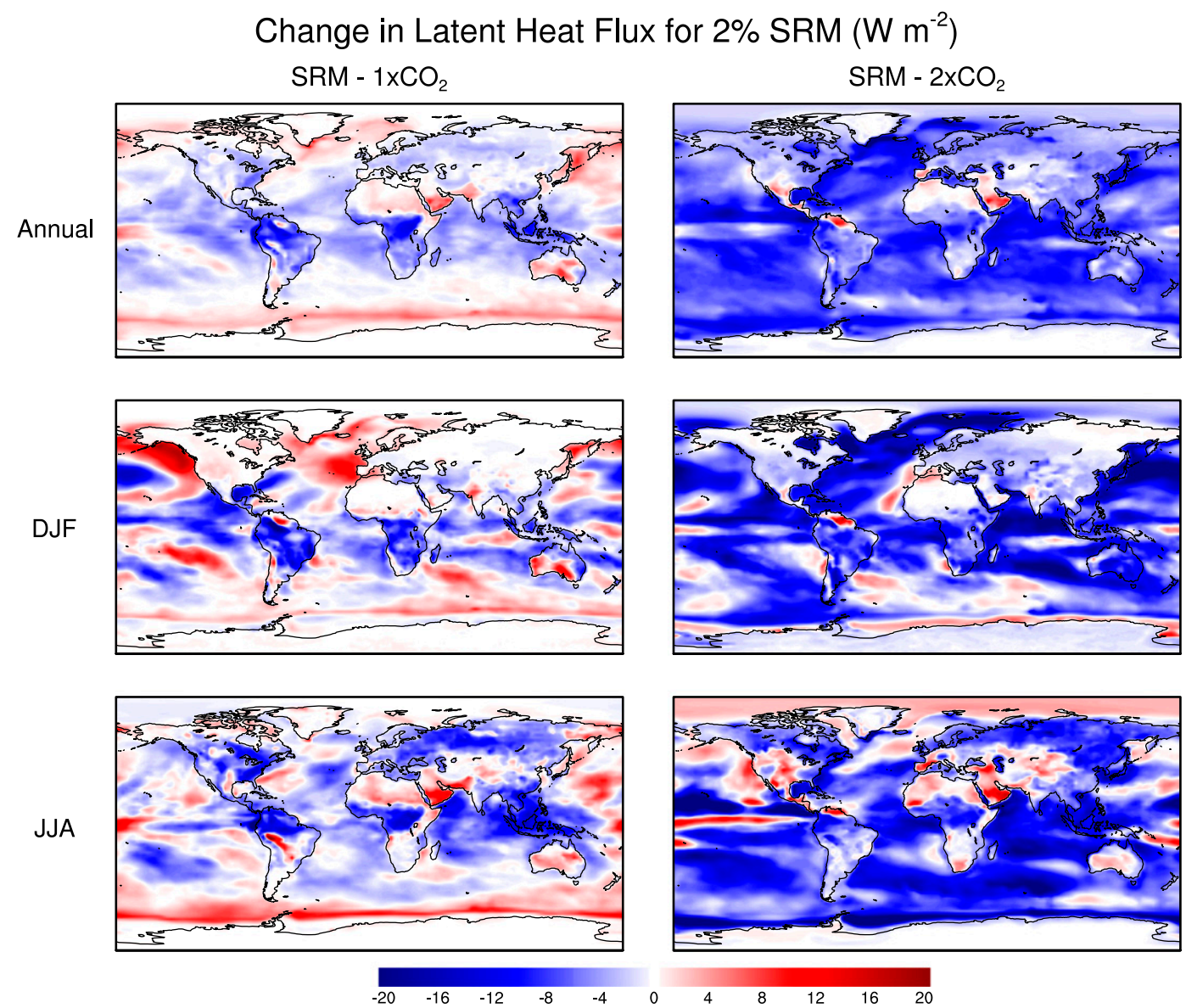

FIG. 2. Latent heat flux changes $\left(\mathrm{W} \mathrm{m}^{-2}\right)$ for the SRM simulation with a $2 \%$ reduction in solar constant, relative to (left) $1 \mathrm{xCO}_{2}$ and (right) $2 \mathrm{xCO}_{2}$. The sign convention is positive upward. (top) Annual mean changes, (middle) DJF changes, and (bottom) JJA changes.

[December-February (DJF)] and increases in boreal summer [June-August (JJA)]. Soil moisture changes in the top $2 \mathrm{~m}$, roughly the entire modeled soil column, reflect a similar pattern (Fig. S7 in the supplementary material). Photosynthesis increases globally by $35.2 \%$ (Fig. 7), primarily because of elevated $\mathrm{CO}_{2}$ concentrations.

Relative to $2 \mathrm{xCO}_{2}$, global mean surface temperature decreases by $2.8 \mathrm{~K}$ in the $2 \%$ SRM simulation (Fig. 1 and Table S4 in the supplementary material), exceeding the change relative to $1 \mathrm{xCO}_{2}$ because the decrease in shortwave radiation is not balanced by an increase in longwave radiation. Latent heat flux over land decreases by $5.8 \%$ (Fig. 2), but now both transpiration and ground evaporation contribute equally to total ET (Fig. 3). Global mean precipitation decreases (Fig. 4), and because this change exceeds the decrease in ET, global mean runoff also decreases (Fig. 5). Global mean changes in water cycling relative to $2 \mathrm{xCO}_{2} \mathrm{ex}$ ceed the magnitude of changes relative to $1 \mathrm{xCO}_{2}$. Soil moisture increases, and the spatial variability persists, with the global mean change only marginally less than changes relative to $1 \mathrm{xCO}_{2}$ (Fig. 6). Photosynthesis increases by a smaller magnitude $(3.2 \%)$ for the $2 \%$ SRM simulation relative to $2 \mathrm{xCO}_{2}$, because both simulations include the $\mathrm{CO}_{2}$ fertilization effect (Fig. 7).

\section{b. Regional changes}

We calculate regional changes for six uniformly sized regions (Fig. S8 in the supplementary material) representing three different climate zones. In the tropics, evapotranspiration decreases during both seasons under SRM relative to $1 \mathrm{xCO}_{2}$ and $2 \mathrm{xCO}_{2}$ (Tables S5-S8 in the supplementary material). Transpiration decreases throughout the Amazon and the Congo and acts as the primary driver of ET decreases (Fig. 3). Runoff and soil moisture decrease in DJF and increase in JJA (except for $3 \%$ SRM relative to $2 \mathrm{xCO}_{2}$ ). For the Congo, runoff increases in JJA relative to $1 \mathrm{xCO}_{2}$ are greater than $100 \%$ for both $2 \%$ and 3\% SRM (Fig. 5). Photosynthesis increases in both seasons (Fig. 7). 


\section{Change in Evapotranspiration Fluxes for 2\% SRM (mm day ${ }^{-1}$ )}
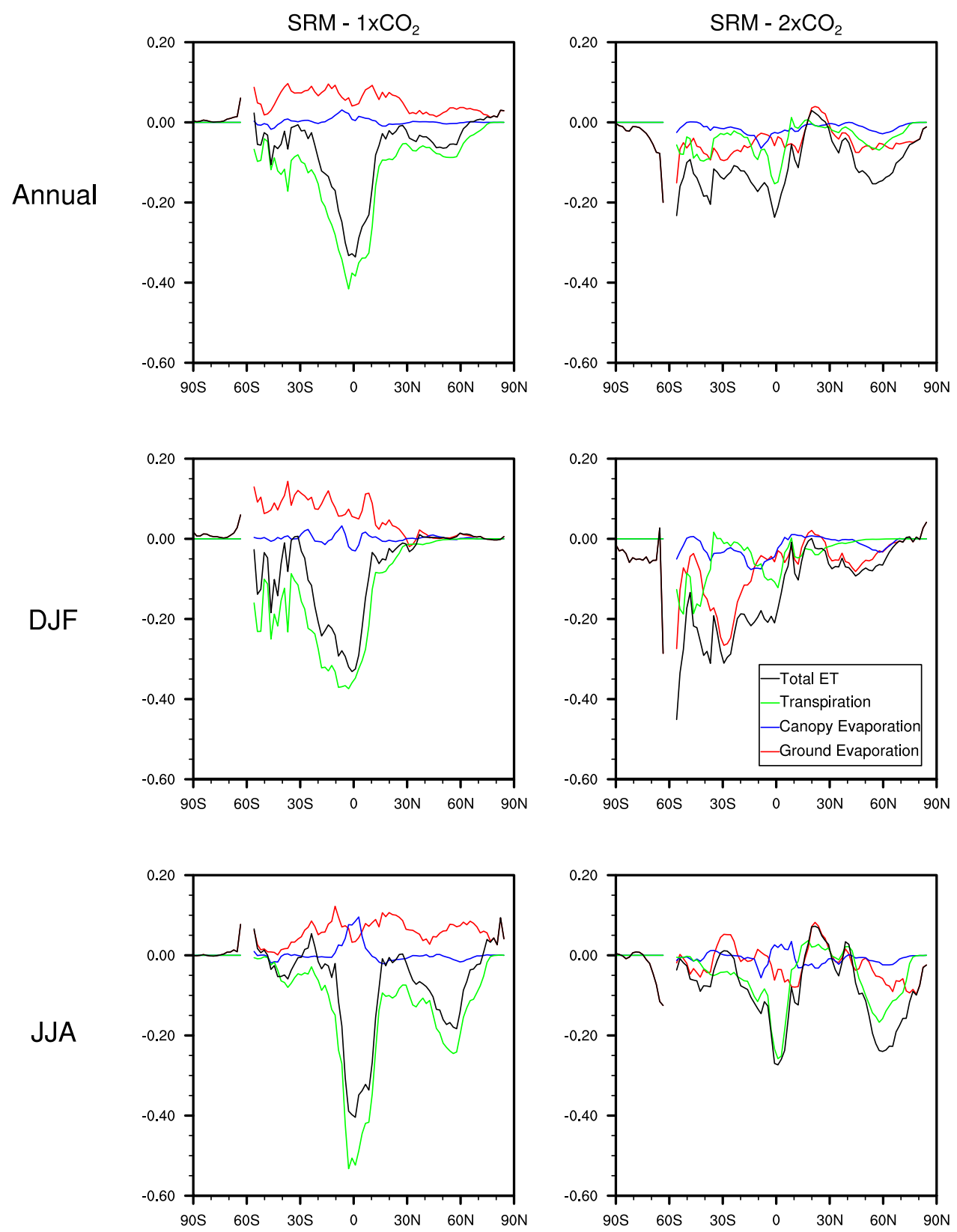

FIG. 3. Zonal mean changes in land evaporative fluxes $\left(\mathrm{mm} \mathrm{day}^{-1}\right)$ for the SRM simulation with a $2 \%$ reduction in solar constant, relative to (left) $1 \mathrm{xCO}_{2}$ and (right) $2 \mathrm{xCO}_{2}$. Legend coloring applies to all figures. (top) Annual mean changes, (middle) DJF changes, and (bottom) JJA changes.

ET increases in DJF and decreases in JJA in the northern midlatitudes, relative to $1 \mathrm{xCO}_{2}$ (Tables S9-S14 in the supplementary material). ET decreases in both seasons relative to $2 \mathrm{xCO}_{2}$, except in the central United States, where ET increases in JJA because of increases in transpiration. The primary driver to ET changes in DJF is ground evaporation, while the primary driver in
JJA is transpiration (Fig. 3). In western Russia relative to $2 \mathrm{xCO}_{2}$, ground evaporation again dominates ET decreases in DJF, but with some important contributions from canopy evaporation not seen elsewhere. Runoff changes are larger in DJF than in JJA, except in western Europe (Fig. 5). Soil moisture decreases in DJF and increases in JJA (Fig. 6), negatively correlated with ET 




FIG. 4. Precipitation changes $\left(\mathrm{mm} \mathrm{day}^{-1}\right)$ for the SRM simulation with a $2 \%$ reduction in solar constant, relative to (left) $1 \mathrm{xCO}_{2}$ and (right) $2 \mathrm{xCO}_{2}$. (top) Annual mean changes, (middle) DJF changes, and (bottom) JJA changes.

changes relative to $1 \mathrm{xCO}_{2}$. However, there are some exceptions to this response, including in the central United States and western Russia, where soil moisture decreases in JJA despite decreases in ET. Photosynthesis increases during both seasons, except in DJF relative to $2 \mathrm{xCO}_{2}$ (Fig. 7). Seasonal variability of photosynthesis is larger in northern midlatitudes than in the tropics, with changes in JJA larger than changes in DJF.

In the southern subtropics, ground evaporation is the primary driver of ET changes in both seasons (Tables S15 and S16 in the supplementary material). ET, runoff, and soil moisture increase relative to $1 \mathrm{xCO}_{2}$ and decrease relative to $2 \mathrm{xCO}_{2}$. Photosynthesis increases in both seasons, except for JJA relative to $2 \mathrm{xCO}_{2}$ (Fig. 7).

\section{c. Linearity of SRM}

To test the linearity of SRM, we look at the change in temperature, precipitation, ET, runoff, and soil moisture for the 3\% SRM simulation and calculate the deviation of these changes from a linear projection of the changes for the $2 \mathrm{xCO}_{2}$ (analogous to $0 \% \mathrm{SRM}$ ), $1 \%$ SRM, and 2\% SRM simulations (Table 2). We use the sign of the linear projection slope and the sign of the deviation to determine whether the simulated variable from $3 \%$ SRM exceeds or falls short of the prediction (Table 3 ). If the variable exceeds the prediction, the slope is of greater magnitude than expected, implying a positive feedback could be contributing to the nonlinearity. If the variable falls short of the prediction, there could be a negative feedback in the system.

The deviation in global mean temperature is small relative to the linear projection. Precipitation and ET show a nonlinear response, and on a global scale the predictions are of greater magnitude than what is expected from a linear projection. The runoff prediction is smaller than expected with the largest global mean deviation. The soil moisture prediction is also smaller than expected.

Surface temperature deviations are consistent across regions, showing predictions less than expected. The precipitation response is mostly consistent across regions, 


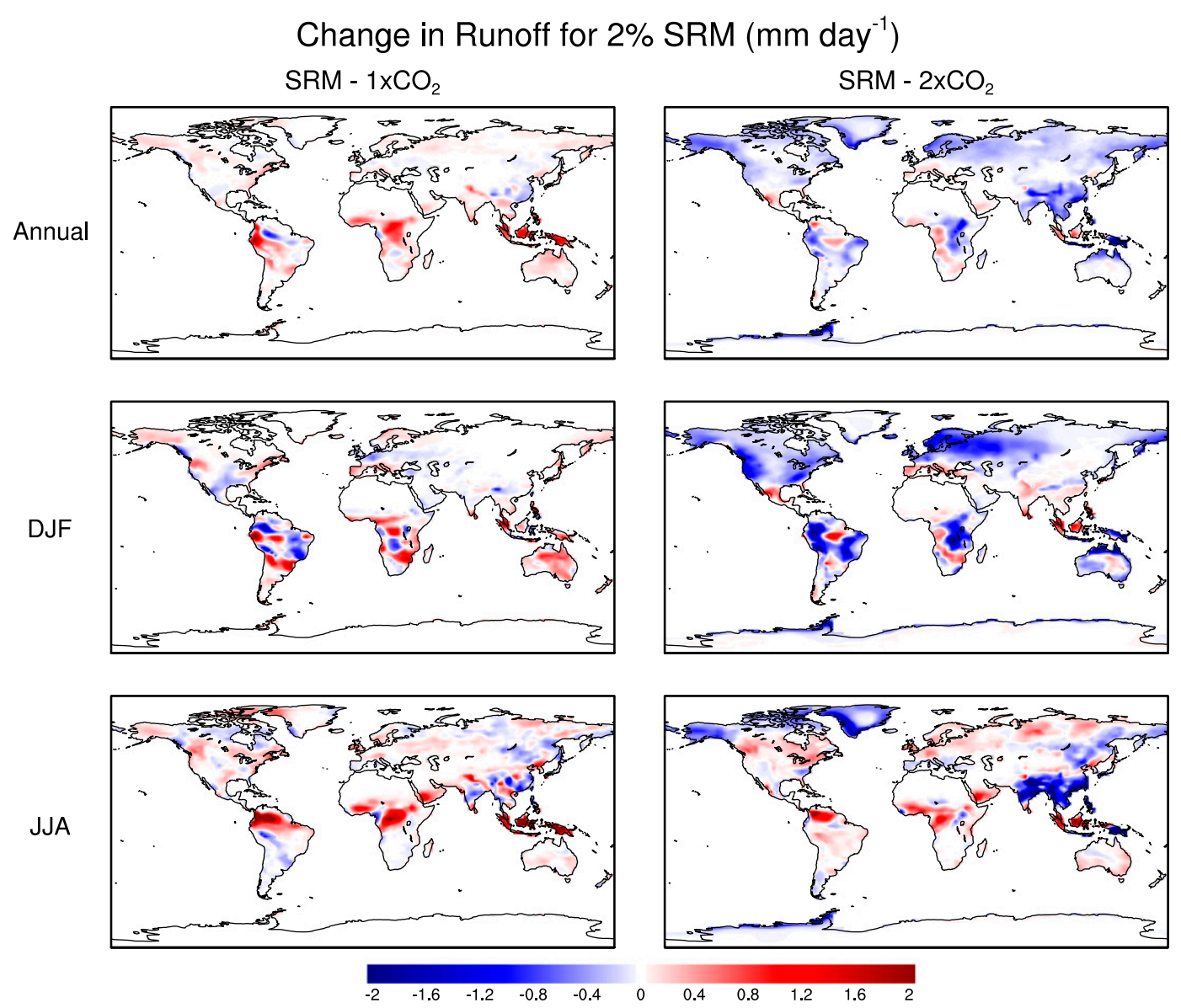

FIG. 5. Runoff [precipitation minus evaporation $(P-E)$ over land] changes $\left(\mathrm{mm} \mathrm{day}^{-1}\right)$ for the SRM simulation with a $2 \%$ reduction in solar constant, relative to (left) $1 \mathrm{xCO}_{2}$ and (right) $2 \mathrm{xCO}_{2}$. (top) Annual mean changes, (middle) DJF changes, and (bottom) JJA changes.

with only the Amazon showing a prediction less than expected and all other regions showing predictions greater than expected (Fig. S9 in the supplementary material). There is similar inconsistency in the ET predictions, where only the response in the Congo differs. The ET deviations are on average larger than the precipitation deviations, except in the tropics. The largest deviations in ET are in the southern subtropics, though this climate zone only included one region. Regional deviations in runoff are also large, but again there is inconsistency in the magnitude of the predictions relative to the projections. Soil moisture changes are less than the projections except in the Amazon and western Europe, with the largest deviations in the tropics.

\section{Discussion}

Our study shows how water cycling between the land and the atmosphere changes under SRM and elevated $\mathrm{CO}_{2}$. Compensating longwave forcing with changes in solar radiation sets off a variety of climate and vegetation feedbacks. These responses have implications for the climate of a high- $\mathrm{CO}_{2}$ world with SRM to compensate anthropogenic climate change. Globally, evapotranspiration decreases under SRM relative to present-day and elevated $\mathrm{CO}_{2}$ concentrations. However the mechanisms are different in each case. Relative to present-day, the $\mathrm{CO}_{2}$ physiological effect decreases transpiration. This decrease exceeds the increase in ground and canopy evaporation, as the atmosphere still demands water from the land despite the decrease in solar radiation. Relative to elevated $\mathrm{CO}_{2}$, less solar energy at the surface drives an overall decrease in ET despite the absence of a physiological effect. Precipitation decreases in each case, but runoff increases relative to present-day, when ET exceeds precipitation, and decreases relative to elevated $\mathrm{CO}_{2}$, when ET falls short of precipitation. Although there is spatial and temporal variability, SRM relative to present-day increases water availability on land, whereas, in the 

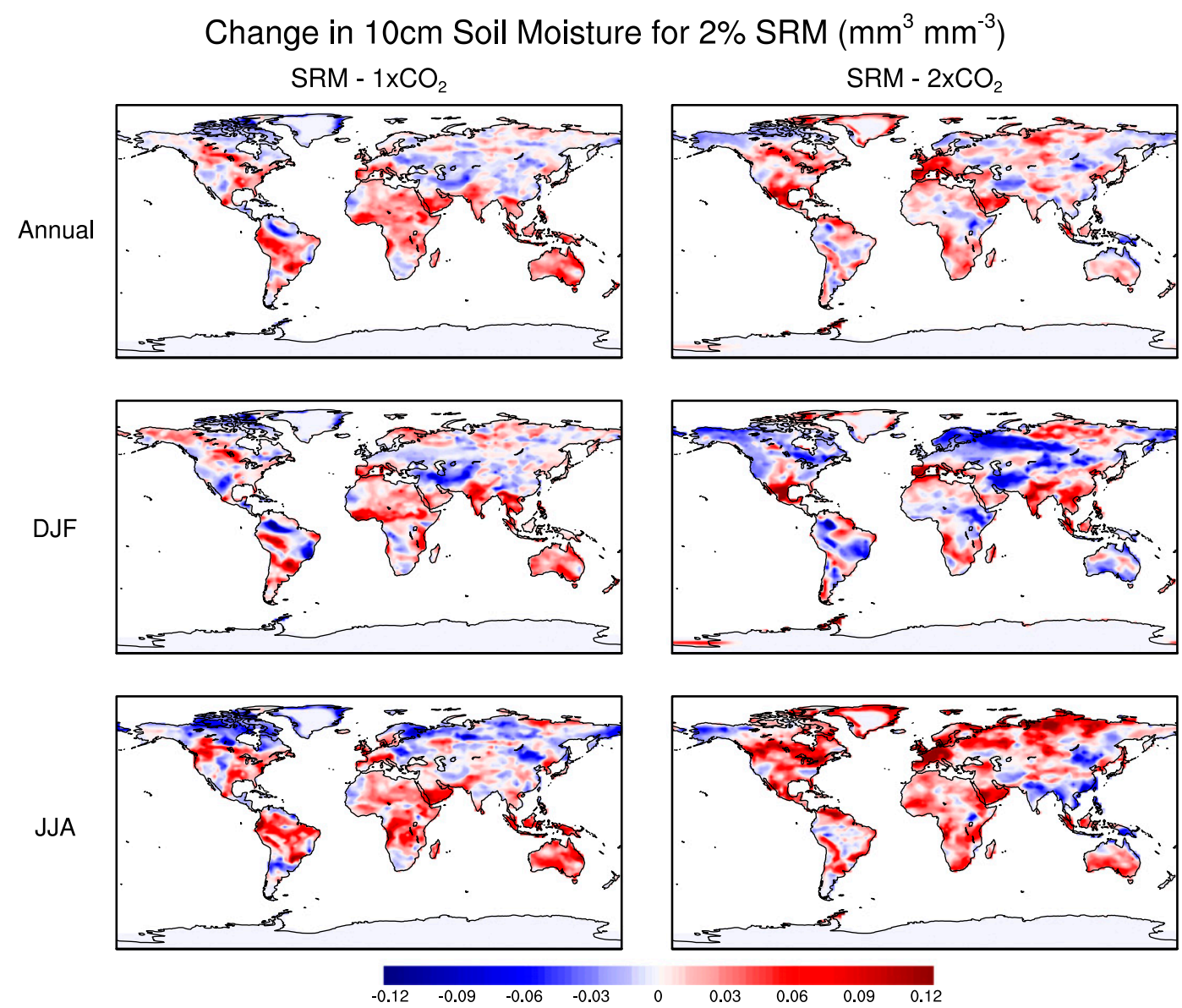

FIG. 6. Top 10-cm volumetric soil moisture changes $\left(\mathrm{mm}^{3} \mathrm{~mm}^{-3}\right)$ for the SRM simulation with a $2 \%$ reduction in solar constant, relative to (left) $1 \mathrm{xCO}_{2}$ and (right) $2 \mathrm{xCO}_{2}$. (top) Annual mean changes, (middle) DJF changes, and (bottom) JJA changes.

comparison with a greenhouse world, water availability decreases.

In the tropics, transpiration decreases because of a combination of increased water use efficiency and decreased solar radiation, driving evapotranspiration decreases. The abundance of vegetation produces a strong $\mathrm{CO}_{2}$ physiological effect with elevated $\mathrm{CO}_{2}$, decreasing stomatal conductance and transpiration. The runoff response is strongly coupled to simulationspecific precipitation and evapotranspiration changes, which can drive very large changes, such as in the Congo during boreal summer, with implications for increased water availability but also increased flood risk (Betts et al. 2007). Regionally averaged soil moisture integrates both changes in the water cycle and vegetation feedbacks. Thus, soil moisture can increase when precipitation decreases, as long as evapotranspiration decreases to compensate. This effect could serve as a mitigation measure for plants to preserve soil water by shutting their stomata when precipitation decreases (Turner 1991; Mitton et al. 1998; Hetherington and Woodward 2003). However, if the decreases in boreal winter runoff and soil moisture persist, the vegetation could experience reduced growth that could further influence both local and global climate (Hilker et al. 2014; Anderegg et al. 2015; Guan et al. 2015).

Northern midlatitudes see an overall decrease in evapotranspiration driven by transpiration in boreal summer and ground evaporation in boreal winter. Decreases in canopy evaporation can also contribute if precipitation sufficiently decreases water supply to the canopy, such as in western Russia during boreal winter. An important area of future research will be to explore the effects of SRM and elevated $\mathrm{CO}_{2}$ on snowpack levels, which are crucial to providing a reservoir of stored water for the following summer season (Cayan 1996; Mote et al. 2005; Belmecheri et al. 2016). While soil moisture is expected to go up when the plants are pulling less water from the soil, decreases in boreal summer evapotranspiration do not always correspond 


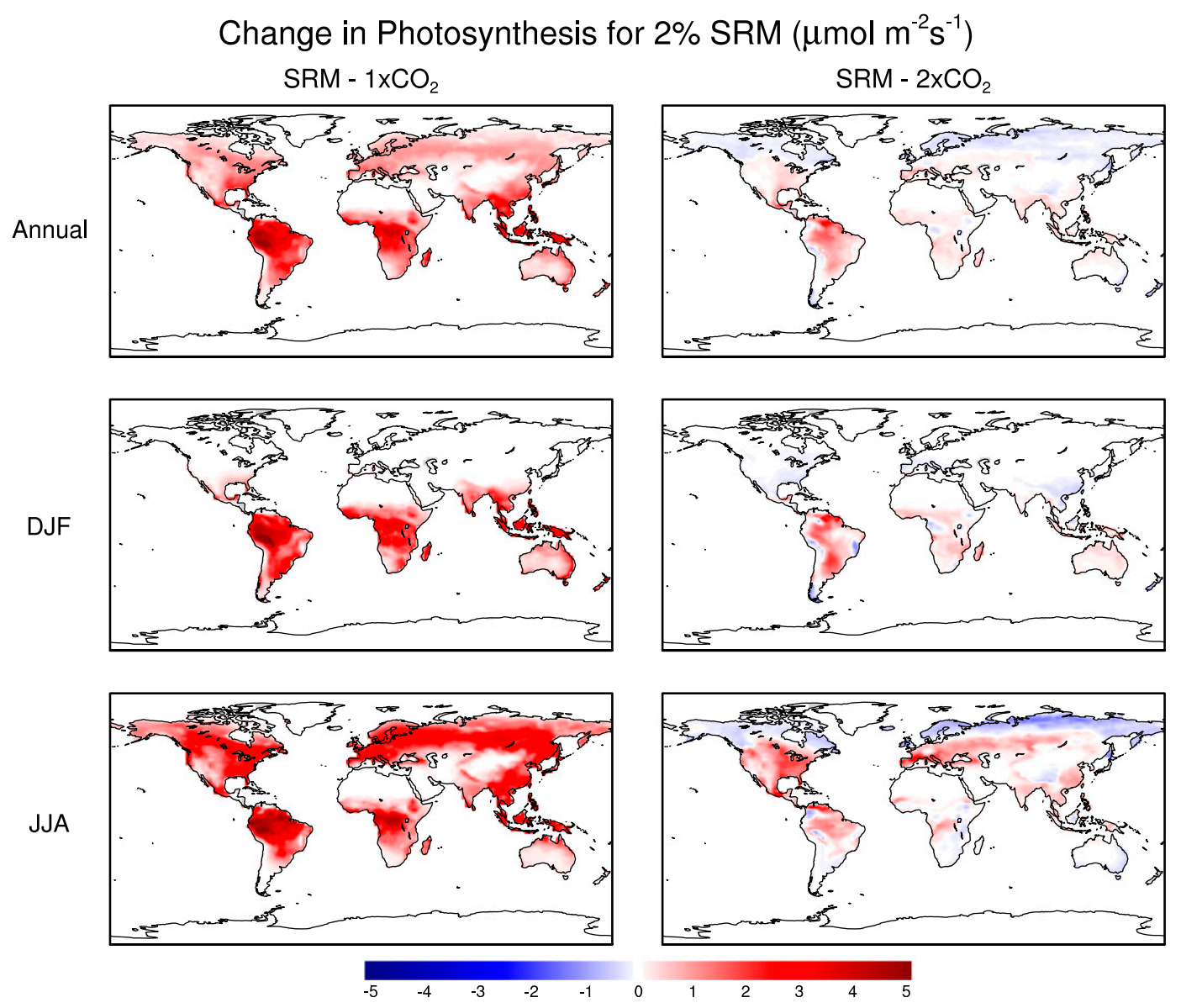

FIG. 7. Photosynthesis changes $\left(\mu \mathrm{mol} \mathrm{m}{ }^{-2} \mathrm{~s}^{-1}\right)$ for the SRM simulation with a $2 \%$ reduction in solar constant, relative to (left) $1 \mathrm{xCO}_{2}$ and (right) $2 \mathrm{xCO}_{2}$. (top) Annual mean changes, (middle) DJF changes, and (bottom) JJA changes.

with soil moisture increases. This effect could be due to an associated decrease in precipitation, though the magnitude is often comparable to ET decreases such that runoff changes are minimal. This relationship does not hold true for boreal winter, when precipitation decreases more than ET, leading to large decreases in runoff. Localized increases in soil moisture observed during boreal summer could act to deter heat waves by providing a buffer of subsurface water, while the heat wave risk could increase if soil moisture decreases (Fischer et al. 2007; Hirschi et al. 2011; Mueller and Seneviratne 2012). The response of photosynthesis in midlatitudes depends on season and choice of control climate simulation, because of the temperature sensitivity of the maximum rate of carboxylation $\left(V_{\mathrm{cmax}}\right)$, which drives overall photosynthetic rates. Thus photosynthesis can increase under SRM relative to $2 \mathrm{xCO}_{2}$, because warmer absolute vegetation temperatures respond to a cooling with an increase in $V_{\text {cmax }}$. We observe this increase in all three northern midlatitude regions in
JJA, while we observe the opposite response in DJF. This effect implies productivity could go up in these regions because of both $\mathrm{CO}_{2}$ fertilization and vegetation cooling, depending on the background mean temperature.

In the southern subtropics, ground evaporation drives total evapotranspiration changes in both seasons. The general lack of vegetation in the interior of the continent explains the minimal contribution of transpiration. ET changes are correlated with runoff and soil moisture changes such that all three variables increase relative to present-day and decrease relative to elevated $\mathrm{CO}_{2}$. The ET increase could be due to a shift in surface heat flux partitioning from sensible to latent when solar radiation decreases in conjunction with higher $\mathrm{CO}_{2}$ (Kravitz et al. 2013b). Precipitation also increases, which supports a potential shift of arid conditions to a wetter climate.

We find that water cycling is nonlinear with SRM, most likely driven by the nature of the precipitation response to decreased solar radiation (Irvine et al. 2010). Unlike the temperature response to a cooling from 
TABLE 2. Deviations of modeled changes for the 3\% SRM simulation (simulated value) from a linear projection of the changes due to the $2 \mathrm{xCO}_{2}(0 \% \mathrm{SRM}), 1 \% \mathrm{SRM}$, and $2 \% \mathrm{SRM}$ simulations (predicted value). The linear projection is calculated by the method of least squares. Changes are relative to the $1 \mathrm{xCO}_{2}$ simulation. Runoff is defined as $P-E$ over land. Units are percent changes, calculated as the difference between the simulated and predicted values, divided by the magnitude of the predicted value. All values reflect annual means. Specific regions are averaged into climate zones.

\begin{tabular}{lcccr}
\hline \hline & Global mean & Tropics & Northern midlatitudes & Southern subtropics \\
\hline Surface temperature & $0 \%$ & $21.6 \%$ & $18.6 \%$ & $86.1 \%$ \\
Precipitation & $-6.1 \%$ & $-5.8 \%$ & $-17.3 \%$ & $-297.9 \%$ \\
Evapotranspiration & $-9.3 \%$ & $-3.4 \%$ & $-21.5 \%$ & $-635.2 \%$ \\
Runoff & $66.7 \%$ & $43.0 \%$ & $-90.3 \%$ & $-209.8 \%$ \\
10-cm soil moisture & $-13.2 \%$ & $798.3 \%$ & $-53.1 \%$ & $-6.7 \%$ \\
\hline
\end{tabular}

SRM, precipitation responds nonlinearly. This response influences land-atmosphere water cycling as a whole, and thus evapotranspiration, runoff, and soil moisture also show nonlinear responses. This result has implications for the sensitivity of water cycling to the amount of SRM. The hydrologic response may not be predictable in a linear fashion; in fact, on a global scale, changes could be greater than expected. This result also implies there is some memory in the system, such as in soil moisture, which acts to accelerate water cycling changes as the strength of SRM increases (Seneviratne et al. 2006; Lorenz et al. 2010).

There are some important caveats to note in our modeling framework. Our approach parameterizes $\mathrm{SRM}$ as a fixed percent reduction in solar radiation instead of modeling the chemistry explicitly through the presence of aerosols in the stratosphere. This method may be appropriate for looking at surface energy balance consequences, but not when considering chemical or dynamical effects in the upper atmosphere. A recent study found nonlinearities in the modeled precipitation response to different anthropogenic forcings when interactive aerosol chemistry was included (Marvel et al. 2015). In addition, injected stratospheric aerosols will result in more spatial and temporal heterogeneity and thus more complicated dynamics than uniform global reductions in solar radiation. Several studies have found global precipitation reductions over land were greater when SRM was modeled as a stratospheric aerosol layer than when a solar constant reduction was used (Fyfe et al. 2013; Niemeier et al. 2013; Ferraro et al. 2014). However, another study found climate changes under these two methods of SRM were very similar except for the impacts on stratospheric temperature, chemistry, and dynamics (Kalidindi et al. 2015). Disagreement between studies is most likely due to differences in prescribed aerosol size and spatial distributions, necessitating further analysis.

Our approach did not simulate the effect of diffuse radiation, which would otherwise be present when prescribing an aerosol layer in the model. Aerosols tend to scatter incoming radiation, thus shifting the partitioning of direct and diffuse radiation toward the latter. An increase in diffuse radiation has been shown in both models and observations to increase the productivity of plants, because they are able to more efficiently utilize the incoming radiation without becoming light saturated (Roderick et al. 2001; Gu et al. 2003; Mercado et al. 2009), though in some regions this effect may not compensate for the overall decrease in available light, depending on the canopy structure (Tingley et al. 2014). Compounding this response is the effect of enhanced $\mathrm{CO}_{2}$ uptake on the terrestrial carbon cycle (Foley et al. 2014). After the eruption of Mount Pinatubo, there was an anomalous decrease in atmospheric $\mathrm{CO}_{2}$ from 1992 to 1993 due to an increased carbon sink (Mercado et al. 2009). Possible explanations for this sink include enhanced photosynthesis and suppression of respiration during cold summers. However, some studies have found no evidence of an aerosol-induced increase in net primary production (Krakauer and Randerson 2003; Angert et al. 2004).

There are also some approximations in CLM that likely affect our results. Stomatal conductance and photosynthesis are coupled in the model. Increasing $\mathrm{CO}_{2}$ acts to decrease stomatal conductance but also acts to increase photosynthesis, which acts to indirectly increase stomatal conductance. The former effect wins out, and overall transpiration decreases under elevated $\mathrm{CO}_{2}$ in the model. But there is a question of how much this coupling framework applies in reality (Bonan et al. 2011). While vegetation feedbacks in response to elevated $\mathrm{CO}_{2}$ are well understood as a physiological consequence, uncertainty in the reduction of latent heat flux persists across models (Friedlingstein et al. 2006). This uncertainty is driven by ambiguity in the extent of stomatal closure and the strength of the $\mathrm{CO}_{2}$ fertilization effect in reality (Field et al. 1995; Berry et al. 2010; Fyfe et al. 2013). Transpiration inside a leaf is also far more complex than the typical "big leaf" canopy scaling used 
TABLE 3. Summary of simulated global and regional mean changes relative to linear projections. A positive sign (+) indicates the variable change for the $3 \%$ SRM simulation exceeds the magnitude of the predicted value from a linear projection of the changes due to the $2 \mathrm{xCO}_{2}(0 \% \mathrm{SRM}), 1 \% \mathrm{SRM}$, and $2 \% \mathrm{SRM}$ simulations. Changes are relative to the $1 \mathrm{xCO}_{2}$ simulation. A negative sign ( -$)$ indicates the change falls shorts of the magnitude of the predicted value. No sign is used where there is no significant difference between the simulated and predicted values.

\begin{tabular}{lccccccc}
\hline \hline & Global mean & Amazon & Congo & Central United States & Western Europe & Western Russia & Australia \\
\hline Surface temperature & & - & - & - & - & & - \\
Precipitation & + & - & + & + & + & + & + \\
Evapotranspiration & + & + & - & + & + & + & + \\
Runoff & - & + & + & - & + & + \\
10-cm soil moisture & - & + & - & - & + & - \\
\hline
\end{tabular}

in the current modeling framework (Bonan 2008; Rockwell et al. 2014). Furthermore, recent work has suggested forest water use efficiency under elevated $\mathrm{CO}_{2}$ is underestimated across the commonly used terrestrial biosphere models (Keenan et al. 2013), which would have implications for modeled evapotranspiration changes in a world with SRM and increased $\mathrm{CO}_{2}$.

Plant response in reality may also include shifting vegetation dynamics, including leaf area index (Kergoat et al. 2002), vegetation distributions (Betts et al. 1997; Franks et al. 2013), surface albedo (Bala et al. 2006; Swann et al. 2012), land use change (Albani et al. 2006), and age-dependent physiological factors on the biochemical capacity for photosynthesis (Sellers et al. 1996a), none of which are considered here. One study that did include leaf area changes with elevated $\mathrm{CO}_{2}$ found that the effect on total evapotranspiration through increased canopy evaporation of intercepted water was small relative to the induced physiological changes in stomatal conductance and transpiration, most likely because of decreased precipitation (Fyfe et al. 2013). The current version of the model used here does not include carbon-nitrogen cycling, which affects nutrient balance as well as water cycling. In particular, a lack of nitrogen limitation can greatly exaggerate the modeled photosynthetic response (Thornton et al. 2007, 2009). Modeling the nitrogen cycle has also been shown to be important for simulations of terrestrial net primary productivity under SRM (Jones et al. 2013; Irvine et al. 2014; Glienke et al. 2015).

Modeling SRM provides a way to artificially separate the $\mathrm{CO}_{2}$ radiative and physiological effects. The FreeAir $\mathrm{CO}_{2}$ Enrichment (FACE) projects attempt to separate out the physiological effect in situ, providing an observational analog to this work (Long et al. 2004; Norby and Zak 2011). Many of the short-term FACE studies have shown enhanced $\mathrm{CO}_{2}$ to cause a wide range of responses in forests, compounded by a variety of environmental and physiological factors (Reich et al. 2006; Leakey et al. 2009; De Kauwe et al. 2013; Franks et al. 2013). SRM could be an enhancement for ecosystems if decreased stomatal conductance leads to increased water use efficiency and higher productivity rates, though recent studies have shown this response may not be consistent across spatial and temporal scales (Reich et al. 2014; van der Sleen et al. 2014; Medlyn et al. 2015). Furthermore, the nature of the enhancement may or may not be beneficial, depending on vegetation type and region of the world (Govindasamy et al. 2002; Robock and Li 2006; Pongratz et al. 2012; Fyfe et al. 2013; Xia et al. 2014). However, these assumptions may change over time as plants acclimate to elevated $\mathrm{CO}_{2}$ (Sellers et al. 1996a; Drake et al. 1997; Ainsworth and Rogers 2007).

Despite these caveats, our results illustrate the potential water cycling response to geoengineering by solar radiation management. There are significant hydrologic implications when decreased shortwave forcing compensates for increased longwave forcing from greenhouse gases. Both the physiological effect of $\mathrm{CO}_{2}$ on vegetation and decreased solar radiation at the surface from SRM drive the climate response. Competing effects between water in plants, water in soils, and the atmospheric demand for water lead to regional and seasonal heterogeneities in the overall hydrologic response to SRM. These effects can vary only slightly but have the potential for significant consequences.

\section{Conclusions}

In our study, SRM implemented in a high- $\mathrm{CO}_{2}$ world does not mitigate changes in land-atmosphere water cycling. Decreasing shortwave forcing to compensate for increased longwave forcing from greenhouse gases creates an asymmetry in the hydrologic cycle response, driven by the direct effect of $\mathrm{CO}_{2}$ on vegetation. We find evapotranspiration decreases because of increased water use efficiency and decreased stomatal conductance under SRM. The combined response of precipitation and evapotranspiration influence runoff, the direction of which depends on region and season. Water cycling and 
vegetation-climate feedbacks influence local soil moisture. These results have implications for vegetation productivity and local climate.

However, the modeled response of water cycling depends on model-specific vegetation and soil parameterizations. In addition to the mechanisms explored in this study, vegetation dynamics and land use changes will influence the response of water cycling between the land and the atmosphere in ways not captured in the current generation of climate models. Soils exhibit greater variability than the composition of a land model grid cell; the same is true of vegetation, which is more complex than a set of fixed plant functional types. Nevertheless, our results highlight potential tradeoffs between geoengineering and the climate of a warmer world.

Acknowledgments. The computations in this paper were run on the Odyssey cluster supported by the FAS Division of Science, Research Computing Group at Harvard University. We thank Abigail L. S. Swann, Ethan E. Butler, and Peter J. Irvine for useful comments on the manuscript. We thank the editor and three anonymous reviewers for suggestions that improved the paper.

\section{REFERENCES}

Ainsworth, E. A., and A. Rogers, 2007: The response of photosynthesis and stomatal conductance to rising $\left[\mathrm{CO}_{2}\right]$ : Mechanisms and environmental interactions. Plant Cell Environ., 30, 258-270, doi:10.1111/j.1365-3040.2007.01641.x.

Albani, M., D. Medvigy, G. C. Hurtt, and P. R. Moorcroft, 2006: The contributions of land-use change, $\mathrm{CO}_{2}$ fertilization, and climate variability to the Eastern US carbon sink. Global Change Biol., 12, 2370-2390, doi:10.1111/ j.1365-2486.2006.01254.x.

Allen, M. R., and W. J. Ingram, 2002: Constraints on future changes in climate and the hydrologic cycle. Nature, 419, 224-232, doi:10.1038/nature01092.

Ammann, C. M., W. M. Washington, G. A. Meehl, L. Buja, and H. Teng, 2010: Climate engineering through artificial enhancement of natural forcings: Magnitudes and implied consequences. J. Geophys. Res., 115, D22109, doi:10.1029/ 2009JD012878.

Anderegg, W. R. L., and Coauthors, 2015: Pervasive drought legacies in forest ecosystems and their implications for carbon cycle models. Science, 349, 528-532, doi:10.1126/ science.aab1833.

Andrews, T., P. M. Forster, and J. M. Gregory, 2009: A surface energy perspective on climate change. J. Climate, 22, 2557-2570, doi:10.1175/2008JCLI2759.1.

-, M. Doutriaux-Boucher, O. Boucher, and P. M. Forster, 2011: A regional and global analysis of carbon dioxide physiological forcing and its impact on climate. Climate Dyn., 36, 783-792, doi:10.1007/s00382-010-0742-1.

Angert, A., S. Biraud, C. Bonfils, W. Buermann, and I. Fung, 2004: $\mathrm{CO}_{2}$ seasonality indicates origins of post-Pinatubo sink. Geophys. Res. Lett., 31, L11103, doi:10.1029/2004GL019760.
Archer, D., and V. Brovkin, 2008: The millennial atmospheric lifetime of anthropogenic $\mathrm{CO}_{2}$. Climatic Change, 90, 283-297, doi:10.1007/s10584-008-9413-1.

Bala, G., K. Caldeira, A. Mirin, M. Wickett, C. Delire, and T. J. Phillips, 2006: Biogeophysical effects of $\mathrm{CO}_{2}$ fertilization on global climate. Tellus, 58B, 620-627, doi:10.1111/ j.1600-0889.2006.00210.x.

, P. B. Duffy, and K. E. Taylor, 2008: Impact of geoengineering schemes on the global hydrological cycle. Proc. Natl. Acad. Sci. USA, 105, 7664-7669, doi:10.1073/pnas.0711648105.

_ K. Kaldeira, and R. Nemani, 2010: Fast versus slow response in climate change: Implications for the global hydrological cycle. Climate Dyn., 35, 423-434, doi:10.1007/ s00382-009-0583-y.

Ball, J. T., I. E. Woodrow, and J. B. Berry, 1987: A model predicting stomatal conductance and its contribution to the control of photosynthesis under different environmental conditions. Prog. Photosynth. Res., 4, 221-224, doi:10.1007/ 978-94-017-0519-6_48.

Belmecheri, S., F. Babst, E. R. Wahl, D. W. Stahle, and V. Trouet, 2016: Multi-century evaluation of Sierra Nevada snowpack. Nat. Climate Change, 6, 2-3, doi:10.1038/nclimate2809.

Berry, J. A., D. J. Beerling, and P. J. Franks, 2010: Stomata: Key players in the earth system, past and present. Curr. Opin. Plant Biol., 13, 232-239, doi:10.1016/j.pbi.2010.04.013.

Betts, R. A., P. M. Cox, S. E. Lee, and F. I. Woodward, 1997: Contrasting physiological and structural vegetation feedbacks in climate change simulations. Nature, 387, 796-799, doi:10.1038/42924.

— , and Coauthors, 2007: Projected increase in continental runoff due to plant responses to increasing carbon dioxide. Nature, 448, 1037-1041, doi:10.1038/nature06045.

Bitz, C. M., K. M. Shell, P. R. Gent, D. A. Bailey, G. Danabasoglu, K. C. Armour, M. M. Holland, and J. T. Kiehl, 2012: Climate sensitivity of the Community Climate System Model, Version 4. J. Climate, 25, 3053-3070, doi:10.1175/JCLI-D-11-00290.1.

Bonan, G. B., 2008: Ecological Climatology. Cambridge University Press, $690 \mathrm{pp}$.

— S. Levis, L. Kergoat, and K. W. Oleson, 2002: Landscapes as patches of plant functional types: An integrating concept for climate and ecosystem models. Global Biogeochem. Cycles, 16, 5-1-5-23, doi:10.1029/2000GB001360.

, P. J. Lawrence, K. W. Oleson, S. Levis, M. Jung, M. Reichstein, D. M. Lawrence, and S. C. Swenson, 2011: Improving canopy processes in the Community Land Model version 4 (CLM4) using global flux fields empirically inferred from FLUXNET data. J. Geophys. Res., 116, G02014, doi:10.1029/2010JG001593.

Boucher, O., A. Jones, and R. A. Betts, 2009: Climate response to the physiological impact of carbon dioxide on plants in the Met Office Unified Model HadCM3. Climate Dyn., 32, 237249, doi:10.1007/s00382-008-0459-6.

Caldeira, K., and L. Wood, 2008: Global and Arctic climate engineering: Numerical model studies. Philos. Trans. Roy. Soc. London, A366, 4039-4056, doi:10.1098/rsta.2008.0132.

Cao, L., G. Bala, K. Caldeira, R. Nemani, and G. Ban-Weiss, 2009: Climate response to physiological forcing of carbon dioxide simulated by the coupled Community Atmosphere Model (CAM3.1) and Community Land Model (CLM3.0). Geophys. Res. Lett., 36, L10402, doi:10.1029/2009GL037724.

,,,,---- and $-\frac{1}{-}$, Importance of carbon dioxide physiological forcing to future climate change. Proc. Natl. Acad. Sci. USA, 107, 9513-9518, doi:10.1073/pnas.0913000107. 
,-- , and -2012 : Climate response to changes in atmospheric carbon dioxide and solar irradiance on the time scale of days to weeks. Environ. Res. Lett., 7, 034015, doi:10.1088/ 1748-9326/7/3/034015.

Cayan, D. R., 1996: Interannual climate variability and snowpack in the western United States. J. Climate, 9, 928-948, doi:10.1175/1520-0442(1996)009<0928:ICVASI>2.0.CO;2.

Cess, R. D., and Coauthors, 1990: Intercomparison and interpretation of climate feedback processes in 19 atmospheric general circulation models. J. Geophys. Res., 95, 16 601-16 615, doi:10.1029/JD095iD10p16601.

Clapp, R. B., and G. M. Hornberger, 1978: Empirical equations for some soil hydraulic properties. Water Resour. Res., 14, 601-604, doi:10.1029/WR014i004p00601.

Collatz, G. J., J. T. Ball, C. Grivet, and J. A. Berry, 1991: Physiological and environmental regulation of stomatal conductance, photosynthesis and transpiration: a model that includes laminar boundary layer. Agric. For. Meteor., 54, 107-136, doi:10.1016/0168-1923(91)90002-8.

Crutzen, P. J., 2006: Albedo enhancement by stratospheric sulfur injections: A contribution to resolve a policy dilemma? Climatic Change, 77, 211-220, doi:10.1007/s10584-006-9101-y.

Curry, C. L., and Coauthors, 2014: A multimodel examination of climate extremes in an idealized geoengineering experiment. J. Geophys. Res. Atmos., 119, 3900-3923, doi:10.1002/2013JD020648.

Danabasoglu, G., and P. R. Gent, 2009: Equilibrium climate sensitivity: Is it accurate to use a slab ocean model? J. Climate, 22, 2494-2499, doi:10.1175/2008JCLI2596.1.

De Kauwe, M. G., and Coauthors, 2013: Forest water use and water use efficiency at elevated $\mathrm{CO}_{2}$ : A model-data intercomparison at two contrasting temperate forest FACE sites. Global Change Biol., 19, 1759-1779, doi:10.1111/gcb.12164.

Doutriaux-Boucher, M., M. J. Webb, J. M. Gregory, and O. Boucher, 2009: Carbon dioxide induced stomatal closure increases radiative forcing via a rapid reduction in low cloud. Geophys. Res. Lett., 36, L02703, doi:10.1029/2008GL036273.

Drake, B. G., M. A. Gonzàlez-Meler, and S. P. Long, 1997: More efficient plants: A consequence of rising atmospheric $\mathrm{CO}_{2}$ ? Annu. Rev. Plant Physiol. Plant Mol. Biol., 48, 609-639, doi:10.1146/annurev.arplant.48.1.609.

Farquhar, G. D., S. von Caemmerer, and J. A. Berry, 1980: A biochemical model of photosynthetic $\mathrm{CO}_{2}$ assimilation in leaves of $\mathrm{C}_{3}$ species. Planta, 149, 78-90, doi:10.1007/ BF00386231.

Ferraro, A. J., E. J. Highwood, and A. J. Charlton-Perez, 2014: Weakened tropical circulation and reduced precipitation in response to geoengineering. Environ. Res. Lett., 9, 014001, doi:10.1088/1748-9326/9/1/014001.

Field, C. B., R. B. Jackson, and H. A. Mooney, 1995: Stomatal responses to increased $\mathrm{CO}_{2}$ : Implications from the plant to the global scale. Plant Cell Environ., 18, 1214-1225, doi:10.1111/ j.1365-3040.1995.tb00630.x.

Fischer, E. M., S. I. Seneviratne, D. Lüthi, and C. Schär, 2007: Contribution of land-atmosphere coupling to recent European summer heat waves. Geophys. Res. Lett., 34, L06707, doi:10.1029/2006GL029068.

—, J. Rajczak, and C. Schar, 2012: Changes in European summer temperature variability revisited. Geophys. Res. Lett., 39, 1033-1037, doi:10.1029/2012GL052730.

Foley, A. M., M. Willeit, V. Brovkin, G. Feulner, and A. D. Friend, 2014: Quantifying the global carbon cycle response to volcanic stratospheric aerosol radiative forcing using Earth System Models. J. Geophys. Res. Atmos., 119, 101-111, doi:10.1002/2013JD019724.
Franks, P. J., and Coauthors, 2013: Sensitivity of plants to changing atmospheric $\mathrm{CO}_{2}$ concentration: From the geological past to the next century. New Phytol., 197, 1077-1094, doi:10.1111/ nph.12104.

Friedlingstein, P., and Coauthors, 2006: Climate-carbon cycle feedback analysis: Results from the $\mathrm{C}^{4} \mathrm{MIP}$ model intercomparison. J. Climate, 19, 3337-3353, doi:10.1175/JCLI3800.1.

Fyfe, J. C., J. N. S. Cole, V. K. Arora, and J. F. Scinocca, 2013: Biogeochemical carbon coupling influences global precipitation in geoengineering experiments. Geophys. Res. Lett., 40, 651-655, doi:10.1002/grl.50166.

Gettelman, A., J. E. Kay, and K. M. Shell, 2012: The evolution of climate sensitivity and climate feedbacks in the Community Atmosphere Model. J. Climate, 25, 1453-1469, doi:10.1175/ JCLI-D-11-00197.1.

Gillett, N. P., A. J. Weaver, F. W. Zwiers, and M. F. Wehner, 2004: Detection of volcanic influence on global precipitation. Geophys. Res. Lett., 31, L12217, doi:10.1029/2004GL020044.

Glienke, S., P. J. Irvine, and M. G. Lawrence, 2015: The impact of geoengineering on vegetation in experiment G1 of the GeoMIP. J. Geophys. Res. Atmos., 120, 10 196-10213, doi:10.1002/ 2015JD024202.

Govindasamy, B., and K. Caldeira, 2000: Geoengineering Earth's radiation balance to mitigate $\mathrm{CO}_{2}$-induced climate change. Geophys. Res. Lett., 27, 2141-2144, doi:10.1029/1999GL006086.

- - S. Thompson, P. B. Duffy, K. Caldeira, and C. Delire, 2002: Impact of geoengineering schemes on the terrestrial biosphere. Geophys. Res. Lett., 29, 2061, doi:10.1029/ 2002GL015911.

— K. Kaldeira, and P. B. Duffy, 2003: Geoengineering Earth's radiation balance to mitigate climate change from a quadrupling of $\mathrm{CO}_{2}$. Global Planet. Change, 37, 157-168, doi:10.1016/ S0921-8181(02)00195-9.

Gu, L., D. D. Baldocchi, S. C. Wofsy, J. W. Munger, J. J. Michalsky, S. P. Urbanski, and T. A. Boden, 2003: Response of a deciduous forest to the Mount Pinatubo eruption: Enhanced photosynthesis. Science, 299, 2035-2038, doi:10.1126/science.1078366.

Guan, K., and Coauthors, 2015: Photosynthetic seasonality of global tropics forests constrained by hydroclimate. Nat. Geosci., 8, 284-289, doi:10.1038/ngeo2382.

Hetherington, A. M., and F. I. Woodward, 2003: The role of stomata in sensing and driving environmental change. Nature, 424, 901-908, doi:10.1038/nature01843.

Hilker, T., and Coauthors, 2014: Vegetation dynamics and rainfall sensitivity of the Amazon. Proc. Natl. Acad. Sci. USA, 111, 16 041-16046, doi:10.1073/pnas.1404870111.

Hirschi, M., and Coauthors, 2011: Observational evidence for soilmoisture impact on hot extremes in southeastern Europe. Nat. Geosci., 4, 17-21, doi:10.1038/ngeo1032.

Iles, C. E., G. C. Hegerl, A. P. Schurer, and X. Zhang, 2013: The effect of volcanic eruptions on global precipitation. J. Geophys. Res. Atmos., 118, 8770-8786, doi:10.1002/ jgrd.50678.

Irvine, P. J., A. Ridgwell, and D. J. Lunt, 2010: Assessing the regional disparities in geoengineering impacts. Geophys. Res. Lett., 37, L18702, doi:10.1029/2010GL044447.

— , and Coauthors, 2014: Key factors governing uncertainty in the response to sunshade geoengineering from a comparison of the GeoMIP ensemble and a perturbed parameter ensemble. J. Geophys. Res. Atmos., 119, 7946-7962, doi:10.1002/ 2013JD020716.

Jones, A., and Coauthors, 2013: The impact of abrupt suspension of solar radiation management (termination effect) in experiment 
G2 of the Geoengineering Model Intercomparison Project (GeoMIP). J. Geophys. Res. Atmos., 118, 9743-9752, doi:10.1002/ jgrd.50762.

Kalidindi, S., G. Bala, A. Modak, and K. Caldeira, 2015: Modeling of solar radiation management: A comparison of simulations using reduced solar constant and stratospheric sulphate aerosols. Climate Dyn., 44, 2909-2925, doi:10.1007/ s00382-014-2240-3.

Keenan, T. F., D. Y. Hollinger, G. Bohrer, D. Dragoni, J. W. Munger, H. Peter Schmid, and A. D. Richardson, 2013: Increase in forest water-use efficiency as atmospheric carbon dioxide concentrations rise. Nature, 499, 324-327, doi:10.1038/ nature12291.

Keith, D. W., and D. G. MacMartin, 2015: A temporary, moderate and responsive scenario for solar geoengineering. Nat. Climate Change, 5, 201-206, doi:10.1038/nclimate2493.

Kergoat, L., S. Lafont, H. Douville, B. Berthelot, G. Dedieu, S. Planton, and J.-F. Royer, 2002: Impact of doubled $\mathrm{CO}_{2}$ on global-scale leaf area index and evapotranspiration: Conflicting stomatal conductance and LAI responses. J. Geophys. Res., 107, 4808, doi:10.1029/2001JD001245.

Kleidon, A., and M. Renner, 2013: A simple explanation for the sensitivity of the hydrologic cycle to surface temperature and solar radiation and its implications for global climate change. Earth Syst. Dyn., 4, 455-465, doi:10.5194/esd-4-455-2013.

Krakauer, N. Y., and J. T. Randerson, 2003: Do volcanic eruptions enhance or diminish net primary production? Evidence from tree rings. Global Biogeochem. Cycles, 17, 1118, doi:10.1029/ 2003 GB002076.

Kravitz, B., and Coauthors, 2013a: Climate model response from the Geoengineering Model Intercomparison Project (GeoMIP). J. Geophys. Res. Atmos., 118, 8320-8332, doi:10.1002/jgrd.50646. - , and Coauthors, 2013b: An energetic perspective on hydrological cycle changes in the Geoengineering Model Intercomparison Project. J. Geophys. Res. Atmos., 118, 13 087-13 102 doi:10.1002/2013JD020502.

—, D. G. MacMartin, P. J. Rasch, and A. J. Jarvis, 2015: A new method of comparing forcing agents in climate models. J. Climate, 28, 8203-8218, doi:10.1175/JCLI-D-14-00663.1.

Lammertsma, E. I., H. J. Boerde, S. C. Dekker, D. L. Dilcher, A. F. Lotter, and F. Wagner-Cremer, 2011: Global $\mathrm{CO}_{2}$ rise leads to reduced maximum stomatal conductance in Florida vegetation. Proc. Natl. Acad. Sci. USA, 108, 4035-4040, doi:10.1073/ pnas. 1100371108.

Lawrence, D. M., and Coauthors, 2011: Parameterization improvements and functional and structural advances in Version 4 of the Community Land Model. J. Adv. Model. Earth Syst., 3, M03001, doi:10.1029/2011MS000045.

Leakey, A. D. B., E. A. Ainsworth, C. J. Bernacchi, A. Rogers, S. P. Long, and D. R. Ort, 2009: Elevated $\mathrm{CO}_{2}$ effects on plant carbon, nitrogen, and water relations: Six important lessons from FACE. J. Exp. Bot., 60, 2859-2876, doi:10.1093/jxb/erp096.

Lee, J.-E., and Coauthors, 2012: Reduction of tropical land region precipitation variability via transpiration. Geophys. Res. Lett., 39, L19704, doi:10.1029/2012GL053417.

Lee, T. J., and R. A. Pielke, 1992: Estimating the soil surface specific humidity. J. Appl. Meteor., 31, 480-484, doi:10.1175/ 1520-0450(1992)031<0480:ETSSSH > 2.0.CO;2.

Lenderink, G., A. van Ulden, B. van den Hurk, and E. van Meijgaard, 2007: Summertime inter-annual temperature variability in an ensemble of regional model simulations: Analysis of the surface energy budget. Climatic Change, 81, 233-247, doi:10.1007/s10584-006-9229-9.
Long, S. P., E. A. Ainsworth, A. Rogers, and D. R. Ort, 2004: Rising atmospheric carbon dioxide: Plants FACE the future. Annu. Rev. Plant Biol., 55, 591-628, doi:10.1146/ annurev.arplant.55.031903.141610.

Lorenz, R., E. B. Jaeger, and S. I. Seneviratne, 2010: Persistence of heat waves and its link to soil moisture memory. Geophys. Res. Lett., 37, L09703, doi:10.1029/2010GL042764.

MacCracken, M. C., 2009: On the possible use of geoengineering to moderate specific climate change impacts. Environ. Res. Lett., 4, 045107, doi:10.1088/1748-9326/4/4/045107.

Marvel, K., G. A. Schmidt, D. Shindell, C. Bonfils, A. N. LeGrande, L. Nazarenko, and K. Tsigaridis, 2015: Do responses to different anthropogenic forcings add linearly in climate models? Environ. Res. Lett., 10, 104010, doi:10.1088/ 1748-9326/10/10/104010.

McCusker, K. E., D. S. Battisti, and C. M. Bitz, 2012: The climate response to stratospheric sulfate injections and implications for addressing climate emergencies. J. Climate, 25, 3096-3116, doi:10.1175/JCLI-D-11-00183.1.

Medlyn, B. E., and Coauthors, 2015: Using ecosystem experiments to improve vegetation models. Nat. Climate Change, 5, 528-534, doi:10.1038/nclimate2621.

Meehl, G. A., W. M. Washington, T. M. L. Wigley, J. M. Arblaster, and A. Dai, 2003: Solar and greenhouse gas forcing and climate response in the twentieth century. J. Climate, 16, 426-444, doi:10.1175/1520-0442(2003)016<0426:SAGGFA > 2.0.CO;2.

, and Coauthors, 2013: Climate change projections in CESM1 (CAM5) compared to CCSM4. J. Climate, 26, 6287-6308, doi:10.1175/JCLI-D-12-00572.1.

Mercado, L. M., N. Bellouin, S. Sitch, O. Boucher, C. Huntingford, M. Wild, and P. M. Cox, 2009: Impact of changes in diffuse radiation on the global land carbon sink. Nature, 458, 1014-1017, doi:10.1038/nature07949.

Miralles, D. G., A. J. Teuling, C. C. van Heerwaarden, and J. VilàGuerau de Arellano, 2014: Mega-heatwave temperatures due to combined soil desiccation and atmospheric heat accumulation. Nat. Geosci., 7, 345-349, doi:10.1038/ngeo2141.

Mitton, J. B., M. C. Grant, and A. M. Yoshino, 1998: Variation in allozymes and stomatal size in pinyon (Pinus edulis, Pinaceae), associated with soil moisture. Amer. J. Bot., 85, 1262-1265, doi: $10.2307 / 2446636$

Mote, P. W., A. F. Hamlet, M. P. Clark, and D. P. Lettenmaier, 2005: Declining mountain snowpack in western North America. Bull. Amer. Meteor. Soc., 86, 39-49, doi:10.1175/ BAMS-86-1-39.

Mueller, B., and S. I. Seneviratne, 2012: Hot days induced by precipitation deficits at the global scale. Proc. Natl. Acad. Sci. USA, 109, 12 398-12 403, doi:10.1073/pnas.1204330109.

Niemeier, U., H. Schmidt, K. Alterskjær, and J. E. Kristjánsson, 2013: Solar irradiance reduction via climate engineering: Impact of different techniques on the energy balance and the hydrological cycle. J. Geophys. Res. Atmos., 118, $11905-$ 11917, doi:10.1002/2013JD020445.

Norby, R. J., and D. R. Zak, 2011: Ecological lessons from Free-Air $\mathrm{CO}_{2}$ Enrichment (FACE) experiments. Annu. Rev. Ecol. Evol. Syst., 42, 181-203, doi:10.1146/ annurev-ecolsys-102209-144647.

O'Gorman, P. A., R. P. Allan, M. P. Byrne, and M. Previdi, 2012: Energetic constraints on precipitation under climate change. Surv. Geophys., 33, 585-608, doi:10.1007/s10712-011-9159-6.

Oleson, K. W., and Coauthors, 2010: Technical description of version 4.0 of the Community Land Model (CLM). NCAR Tech. Note NCAR/TN-478+STR, 257 pp., doi:10.5065/D6FB50WZ. 
Peng, J., L. Dan, and W. Dong, 2014: Are there interactive effects of physiological and radiative forcing produced by increased $\mathrm{CO}_{2}$ concentration on changes of land hydrological cycle? Global Planet. Change, 112, 64-78, doi:10.1016/j.gloplacha.2013.11.007.

Pongratz, J., D. B. Lobell, L. Cao, and K. Caldeira, 2012: Crop yields in a geoengineered climate. Nat. Climate Change, 2, 101-105, doi:10.1038/nclimate1373.

Rasch, P. J., P. J. Crutzen, and D. B. Coleman, 2008: Exploring the geoengineering of climate using stratospheric sulfate aerosols: The role of particle size. Geophys. Res. Lett., 35, L02809, doi:10.1029/2007GL032179.

Reich, P. B., B. A. Hungate, and Y. Luo, 2006: Carbon-nitrogen interactions in terrestrial ecosystems in response to rising atmospheric carbon dioxide. Annu. Rev. Ecol. Evol. Syst., 37, 611-636, doi:10.1146/annurev.ecolsys.37.091305.110039.

_ S. E. Hobbie, and T. D. Lee, 2014: Plant growth enhancement by elevated $\mathrm{CO}_{2}$ eliminated by joint water and nitrogen limitation. Nat. Geosci., 7, 920-924, doi:10.1038/ngeo2284.

Ricke, K. L., M. G. Morgan, and M. R. Allen, 2010: Regional climate response to solar-radiation management. Nat. Geosci., 3, 537-541, doi:10.1038/ngeo915.

Robock, A., and H. Li, 2006: Solar dimming and $\mathrm{CO}_{2}$ effects on soil moisture trends. Geophys. Res. Lett., 33, L20708, doi:10.1029/ 2006 GL027585.

Rockwell, F. E., N. M. Holbrook, and A. D. Stroock, 2014: The competition between liquid and vapor transport in transpiring leaves. Plant Physiol., 164, 1741-1758, doi:10.1104/pp.114.236323.

Roderick, M. L., G. D. Farquhar, S. L. Berry, and I. R. Noble, 2001: On the direct effect of clouds and atmospheric particles on the productivity and structure of vegetation. Oecologia, 129, 2130, doi:10.1007/s004420100760.

Sakaguchi, K., and X. Zeng, 2009: Effects of soil wetness, plant litter, and under-canopy atmospheric stability on ground evaporation in the Community Land Model (CLM3.5). J. Geophys. Res., 114, D01107, doi:10.1029/2008JD010834.

Schaller, N., J. Sedláček, and R. Knutti, 2014: The asymmetry of the climate system's response to solar forcing changes and its implications for geoengineering scenarios. J. Geophys. Res. Atmos., 119, 5171-5184, doi:10.1002/2013JD021258.

Schmidt, H., and Coauthors, 2012: Solar irradiance reduction to counteract radiative forcing from a quadrupling of $\mathrm{CO}_{2}$ : Climate responses simulated by four Earth system models. Earth Syst. Dyn., 3, 63-78, doi:10.5194/esd-3-63-2012.

Self, S., J. Zhao, R. E. Holasek, R. C. Torres, and A. J. King, 1996: The atmospheric impact of the 1991 Mount Pinatubo eruption. Fire and Mud: Eruptions and Lahars of Mount Pinatubo, Philippines, C. G. Newhall and Punongbayan, R. S., Eds., University of Washington Press, 1089-1115.

Sellers, P. J., and Coauthors, 1996a: Comparison of radiative and physiological effects of doubled atmospheric $\mathrm{CO}_{2}$ on climate. Science, 271, 1402-1406, doi:10.1126/science.271.5254.1402.

_ , and Coauthors, 1996b: A revised land surface parameterization (SiB2) for atmospheric GCMs. Part I: Model formulation. J. Climate, 9, 676-705, doi:10.1175/1520-0442(1996)009<0676: ARLSPF $>2.0 . \mathrm{CO} ; 2$.

- - and Coauthors, 1997: Modeling the exchanges of energy, water, and carbon between continents and the atmosphere. Science, 275, 502-509, doi:10.1126/science.275.5299.502.

Seneviratne, S. I., and Coauthors, 2006: Soil moisture memory in AGCM simulations: Analysis of Global Land-Atmosphere
Coupling Experiment (GLACE) data. J. Hydrometeor., 7, 1090-1112, doi:10.1175/JHM533.1.

, T. Corti, E. L. Davin, M. Hirschi, E. B. Jaeger, I. Lehner, B. Orlowsky, and A. J. Teuling, 2010: Investigating soil moisture-climate interactions in a changing climate: A review. Earth-Sci. Rev., 99, 125-161, doi:10.1016/j.earscirev.2010.02.004.

Shepherd, J., and S. Rayner, 2009: Geoengineering the climate: Science, governance, and uncertainty. The Royal Society Policy Doc. 10/09 RS1636, 82 pp.

Soden, B. J., R. T. Wetherald, G. L. Stenchikov, and A. Robock, 2002: Global cooling after the eruption of Mount Pinatubo: A test of climate feedback by water vapor. Science, 296, 727-730, doi:10.1126/science.296.5568.727.

Swann, A. L. S., I. Fung, and J. C. H. Chiang, 2012: Mid-latitude afforestation shifts general circulation and tropical precipitation. Proc. Natl. Acad. Sci. USA, 109, 712-716, doi:10.1073/pnas.1116706108.

Tang, J., and W. J. Riley, 2013: Impacts of a new bare-soil evaporation formulation on site, regional, and global surface energy and water budgets in CLM4. J. Adv. Model. Earth Syst., 5, 558-571, doi:10.1002/jame.20034.

Teuling, A. J., and Coauthors, 2013: Evapotranspiration amplifies European summer drought. Geophys. Res. Lett., 40, 2071-2075, doi:10.1002/grl.50495.

Thornton, P. E., J.-F. Lamarque, N. A. Rosenbloom, and N. M. Mahowald, 2007: Influence of carbon-nitrogen cycle coupling on land model response to $\mathrm{CO}_{2}$ fertilization and climate variability. Global Biogeochem. Cycles, 21, GB4018, doi:10.1029/ 2006GB002868.

—_, and Coauthors, 2009: Carbon-nitrogen interactions regulate climate-carbon cycle feedbacks: Results from an atmosphereocean general circulation model. Biogeosciences, 6, 2099-2120, doi:10.5194/bg-6-2099-2009.

Tilmes, S., and Coauthors, 2013: The hydrological impact of geoengineering in the Geoengineering Model Intercomparison Project (GeoMIP). J. Geophys. Res. Atmos., 118, 11036 11 058, doi:10.1002/jgrd.50868.

Tingley, M. P., A. R. Stine, and P. Huybers, 2014: Temperature reconstructions from tree-ring densities overestimate volcanic cooling. Geophys. Res. Lett., 41, 7838-7845, doi:10.1002/ 2014GL061268.

Trenberth, K. E., and A. Dai, 2007: Effects of Mount Pinatubo volcanic eruption on the hydrological cycle as an analog of geoengineering. Geophys. Res. Lett., 34, L15702, doi:10.1029/ 2007GL030524.

Turner, N. C., 1991: Measurement and influence of environmental and plant factors on stomatal conductance in the field. Agric. For. Meteor., 54, 137-154, doi:10.1016/ 0168-1923(91)90003-9.

van der Sleen, P., and Coauthors, 2014: No growth stimulation of tropical trees by 150 years of $\mathrm{CO}_{2}$ fertilization but water-use efficiency increased. Nat. Geosci., 8, 24-28, doi:10.1038/ ngeo2313.

Wigley, T. M. L., 2006: A combined mitigation/geoengineering approach to climate stabilization. Science, 314, 452-454, doi:10.1126/science.1131728.

Xia, L., and Coauthors, 2014: Solar radiation management impacts on agriculture in China: A case study in the Geoengineering Model Intercomparison Project (GeoMIP). J. Geophys. Res. Atmos., 119, 8695-8711, doi:10.1002/2013JD020630. 